\title{
Antibiotic susceptibility of microbiota members Escherichia coli strains isolated from stool samples of patients attended Kırıkkale Yüksek intisas Hospital in ten months
}

\section{Kırıkkale Yüiksek îhtisas Hastanesine on aylık süreçte bașvuran hastaların gaita örneklerinden izole edilen mikrobiyota elemanı Escherichia coli izolatlarının antibiyotik duyarlılıkları}

\author{
Serap SÜzÜK ${ }^{1}$ Havva AVCIKÜçÜK², $\quad$ Banu KAŞKATEPE ${ }^{3}, \quad$ Sebahat AKSARAY4
}

\begin{abstract}
Objective: Antibiotic resistance has turned into a global public health problem in all over the world. Intestinal flora bacteria perform many important functions for human health. As a member of microbiota Escherichia coli cause many infections. This study was aimed to determine antibiotic susceptibility of microbiota member $E$. coli isolates against to the antibiotics that used in treatment.
\end{abstract}

Methods: One hundred and fifty stool samples, which were sent to Kırıkkale Yüksek intisas Hospital microbiology laboratory in a period of between March to December 2013 to study fecal occult blood test and were determined as "negative", were included in this study. E. coli isolates were performed antibiotic susceptibility test by the Kirby Bauer disk diffusion method according to the recommendations of the Clinical Laboratory Standards Institute (CLSI).

Results: A total of 70 out of $150 \mathrm{E}$. coli isolates were sensitive to all antibiotics that used in the study. Twenty four $(16 \%)$ isolates were found to be ESBL producers. All isolates were found sensitive to carbapenems.

Conclusion: It was reached the conclusion that monitoring to resistance profiles of microbiota member $E$. coli isolates, especially in specific group patients in addition to infection agents, is important for giving direction to empirical therapy.

Key Words: Antimicrobial susceptibility, E. coli, microbiota

\section{ÖZET}

Amaç: Antibiyotik direnci, tüm dünyada global bir halk sağlığı sorunu haline dönüșmüștür. Bağırsak florası bakterileri, insan sağığı adına birçok önemli görevi yerine getirirler. Mikrobiyota üyesi olarak Escherichia coli birçok enfeksiyona neden olmaktadır. $\mathrm{Bu}$ çalıșmada mikrobiyota üyesi $E$. coli izolatlarının tedavide kullanılan antibiyotiklere karșı antibiyotik duyarıııklarını belirlemeyi amaçladık.

Yöntemler: Kırıkkale Yüksek İhtisas Hastanesi, Mikrobiyoloji Laboratuvarına Mart-Aralık 2013 tarihleri arasında gaitada gizli kan araștırılması için gönderilen ve “negatif” sonuç çıkan 150 gaita örneği değerlendirmeye alındı. E. coli izolatlarının antibiyotik duyarılık testi Kirby Bauer disk diffüzyon yöntemiyle yapıldı ve sonuçlar Clinical Laboratory Standards Institute (CLSI) standardlarına göre değerlendirildi.

Bulgular: Yüz elli E. coli izolatının 70 tanesi çalıșılan tüm antibiyotiklere duyarlı bulundu. İzolatların 24 (\%16)'ünde genișlemiș spektrumlu betalaktamaz saptandı. İzolatların tümü karbapenemlere duyarlı bulundu.

Sonuç: Mikrobiyota elemanı E. coli izolatlarının direnç profillerinin özellikle spesifik hasta gruplarında izlenmesinin ve enfeksiyon ajanlarına karșı ampirik tedavinin belirlenmesinde önemli olacağı kanısına varılmıștır.

Anahtar Kelimeler: Antimikrobiyal duyarlılık, E. coli, mikrobiyota

1 Public Health Institution of Turkey, National Antimicrobial Resistance Laboratory, ANKARA, TURKEY

29 Mayss State Hospital, Microbiology Laboratory, ANKARA, TURKEY

Ankara University, Faculty of Pharmacy, Department of Pharmaceutical Microbiology, ANKARA, TURKEY

Haydarpaşa Numune Training and Research Hospital, Department of Clinical Microbiology, ISTANBUL, TURKEY

İletişim/Corresponding Author : Serap SÜZÜK

Public Health Institution of Turkey, National Antimicrobial Resistance Laboratory, ANKARA, TURKEY

Tel : +90312565577

E-posta /E-mail : serapsuzuk@gmail.com

Geliş Tarihi / Received : 27.03.2015 Kabul Tarihi / Accepted : 11.06 .2015

DOI ID : 10.5505/TurkHijyen.2015.14880

Süzük S, Avcıküçük H, Kașkatepe B, Aksaray S. Antibiotic susceptibility of microbiota members Escherichia coli strains isolated from stool samples of patients attended Kırıkkale Yüksek intisas Hospital in ten months. Turk Hij Den Biyol Derg, 2015; 72(4): 289-96. 


\section{INTRODUCTION}

Antibiotic resistance has turned into a global public health problem in all over the world (1). Many issues such as excessive or misused antibiotics, inadequately controlled antibiotic usage policy, tourism, refugees, international travel, and lack of hygiene are mediated on the development of antibiotic resistance (2). Antibiotic resistance caused by mutations, enzymes and mechanisms of change in the target region, may be transmitted to the other bacteria through the plasmids, transposons or other mobile resistance elements. This case is mediated with increasing resistance faster than expected $(1,2)$. Escherichia coli $(E$. coli) isolates located in the intestinal flora are involved as a source of resistance genes. These genes can be transferred quickly to other commensal or pathogenic bacteria (3). Microbiota $E$. coli isolates are considered to be a useful indicator in spread of acquired antibiotic resistance genes (4).

Intestinal flora bacteria perform many important functions for human health however in cases of the suppression of the immune system, postsurgical infections and especially in urinary tract infections emerge as the pathogens $(3,5)$. Microbiota $E$. coli strains are agents of especially urinary tract infections (UTI) and sepsis or bacteremia (6). Infections caused by gram negative bacteria are the significant morbidity and mortality factors. Also for the last twenty years, extended spectrum beta lactamase (ESBL) producing gram negative bacteria leads to more serious health problems (7). At the same time both intestinal flora members and ESBL producing bacteria often emerges in hospital-acquired infections (8). These bacteria that carry ESBL enzymes may have an antibiotic-resistance gene to beta-lactam antibiotics and also to aminoglycosides, fluoroquinolones, and trimethoprim-sulfamethoxazole and the infections caused by these multi-drug resistant bacteria can be problem in the treatment (7).

Antibiotic susceptibility profiles of especially community acquired or nosocomial infections agents are included in antibiotic resistance surveillance studies conducted in Turkey. We believe that the microbiota bacteria are important, because of being agents of nosocomial and community acquired infections and also being sources for transfer their resistance genes to the other bacteria. Due to, $E$. coli as a member of microbiota, is the most frequently encountered bacteria in Enterobactericeae family, and also cause many infections, this study was aimed to determine antibiotic susceptibility of microbiota member $E$. coli isolates against to the antibiotics that used in treatment.

\section{MATERIAL and METHOD}

One hundred and fifty stool samples, which were sent to Kırıkkale Yüksek İhtisas Hospital microbiology laboratory in a period of between March to December 2013 to study fecal occult blood test and were determined as "negative", were included in this study.

The first five negative stool samples in order of acceptance to laboratory in everyday were included in the study for randomization. Samples from the same patient were excluded. Single colony inoculation of examples was performed into Eosin Methylene Blue agar (EMB, Klasmed, Turkey) and cultures were incubated for $18-20$ hours at $37^{\circ} \mathrm{C}$. Lactose-positive and metallic green sheen colonies were studied by BBL Crystal E/NF ID System (Becton Dickinson, USA) and antibiotic susceptibility test was performed with bacteria identified as $E$. coli. Antimicrobial susceptibility test of the $E$. coli isolates was performed by the Kirby Bauer disk diffusion method according to the recommendations of the Clinical Laboratory Standards Institute (CLSI) using with Mueller Hinton Agar (MH, KlasMed, Turkey). Antibiotic susceptibility of bacteria was evaluated according to CLSI data and inhibition zone diameters were measured with millimetric ruler. Also ESBL production of bacteria was determined according 
to the CLSI. Accordingly, phenotypic confirmatory test was performed to isolates with zone diameters for ceftazidime $(30 \mu \mathrm{g})<22$ and for cefotaxime $(30 \mu \mathrm{g})<27$. For this ceftazidime-clavulanic acid $(30 / 10 \mu \mathrm{g})$ and cefotaxime-clavulanic acid $(30 / 10 \mu \mathrm{g})$ discs were used. The test were considered ESBL positive if the inhibition zone diameter is $\geq 5 \mathrm{~mm}$ larger with clavulanic acid than without. The quality control of the media, bacterial identification tests and antibiotic discs was performed with E. coli ATCC 25922 strain.

Table 1. Antibiotic susceptibility of $E$. coli isolates

\section{RESULTS}

A total of 150 stool samples, from $92(61.33 \%)$ male and 58 (38.67\%) female patients, were evaluated in the study. The age distribution of the patients ranged from 3 to 88.121 (80.67\%) samples were from outpatients and 29 (19.33\%) from inpatients of all isolates. A total of 70 out of 150 $E$. coli isolates were sensitive to all 23 antibiotics that used in study. Antibiotic susceptibility results of $E$. coli bacteria isolated from intestinal flora are given in Table 1 . Twenty four $(16 \%)$ isolates were

\begin{tabular}{|c|c|c|c|c|}
\hline \multirow{2}{*}{ Antibiotics } & \multicolumn{2}{|c|}{ Susceptibility } & \multicolumn{2}{|c|}{ Resistance } \\
\hline & $\mathrm{n}$ & $\%$ & $\mathrm{n}$ & $\%$ \\
\hline Cefepime & 150 & 100.00 & 0 & 0.00 \\
\hline Imipenem & 150 & 100.00 & 0 & 0.00 \\
\hline Meropenem & 150 & 100.00 & 0 & 0.00 \\
\hline Ertapenem & 150 & 100.00 & 0 & 0.00 \\
\hline Amikacin & 146 & 97.33 & 4 & 2.67 \\
\hline Cefoxcitin & 144 & 96.00 & 6 & 4.00 \\
\hline Cefeperozone & 142 & 94.67 & 8 & 5.33 \\
\hline Gentamicin & 140 & 93.33 & 10 & 6.67 \\
\hline Piperacillin-tazobactam & 138 & 92.00 & 12 & 8.00 \\
\hline Levofloxacin & 129 & 86.00 & 21 & 14.00 \\
\hline Ciprofloxacin & 127 & 84.67 & 23 & 15.33 \\
\hline Cefuroxime (oral) & 126 & 84.00 & 24 & 16.00 \\
\hline Cefotaxime & 126 & 84.00 & 24 & 16.00 \\
\hline Ceftriaxone & 126 & 84.00 & 24 & 16.00 \\
\hline Ceftazidime & 125 & 83.33 & 25 & 16.67 \\
\hline Cefazolin & 122 & 81.33 & 28 & 18.67 \\
\hline Amoxicillin-clavulanic acit & 122 & 81.33 & 28 & 18.67 \\
\hline Ampicillin-sulbactam & 116 & 77.33 & 34 & 22.67 \\
\hline Trimethoprim-sulfamethoxazole & 112 & 74.67 & 38 & 25.33 \\
\hline Piperacillin & 110 & 73.33 & 40 & 26.67 \\
\hline Doxycycline & 106 & 70.67 & 44 & 29.33 \\
\hline Tetracycline & 100 & 66.67 & 50 & 33.33 \\
\hline Ampicillin & 80 & 53.33 & 70 & 46.67 \\
\hline
\end{tabular}


found to be ESBL producers. Antibiotic susceptibility rates of ESBL positive isolates are given in Table 2. All isolates were found sensitive to carbapenems.

Eight samples included in present study were from patients under 16 years. ESBL production is not detected in any of these samples but 2 isolates were found resistant againts to quinolone that not recommended for children. In this group, while the ampicillin susceptibility rate was $50 \%$ and ampicillin sulbactam rate was $75 \%$, amoxicillin clavulanate

Table 2. Antibiotic susceptibility of ESBL positive $E$. coli isolates (\%)

\begin{tabular}{|c|c|c|}
\hline \multirow{2}{*}{ Antibiotics } & \multicolumn{2}{|c|}{ Susceptibility } \\
\hline & $\mathrm{n}$ & (\%) \\
\hline Ampicillin & 0 & 0 \\
\hline Cefazolin & 0 & 0 \\
\hline Cefuroxime (oral) & 0 & 0 \\
\hline Cefotaxime & 0 & 0 \\
\hline Ceftriaxone & 0 & 0 \\
\hline Ceftazidime & 0 & 0 \\
\hline Piperacillin & 4 & 16.67 \\
\hline Ampicillin-sulbactam & 4 & 16.67 \\
\hline Amoxicillin-clavulanic acid & 8 & 33.33 \\
\hline Trimethoprim-sulfamethoxazole & 8 & 33.33 \\
\hline Ciprofloxacin & 11 & 45.83 \\
\hline Levofloxacin & 11 & 45.83 \\
\hline Doxycycline & 12 & 50.00 \\
\hline Tetracycline & 12 & 50.00 \\
\hline Piperacillin-tazobactam & 14 & 58.33 \\
\hline Cefoxcitin & 18 & 75.00 \\
\hline Cefeperozone-sulbactam & 18 & 75.00 \\
\hline Gentamicin & 20 & 83.33 \\
\hline Amikacin & 22 & 91.67 \\
\hline Cefepime & 24 & 100.00 \\
\hline Imipenem & 24 & 100.00 \\
\hline Meropenem & 24 & 100.00 \\
\hline Ertapenem & 24 & 100.00 \\
\hline
\end{tabular}

sensitivity rate was found $100 \%$. Fifty percent of the strains isolated from children were resistant to at least one antibiotic.

\section{DISCUSSION}

The antimicrobial susceptibility studies aim to susceptibility profiles of infection agents as phenotypically or genotypically. The aim of this study was to determine the phenotypic antibiotic susceptibility of microbiota members $E$. coli isolates as a possible source of infection and resistance genes. Although microbiota create beneficial effects on human health, the same bacteria overtake as infectious agents that threaten human health. Besides being a factor for many bacterial infections, it is a resource in terms of antibiotic resistance genes for many bacteria. Moreover, these resistance genes transfer not only between the flora bacteria but also can be transfer to the passes-by bacteria (3). In this respect, the investigation of the resistance profiles of bacterial flora may guide for the basis of empirical therapy, especially both in terms of person and community.

In several studies that shown whether particularly the fecal flora members are UTI factor or not (9, 10). Uropathogenic $E$. coli isolates are located phylogenetically in group B2 and less frequently in the group $\mathrm{D}$. However non-pathogen $E$. coli isolates are often in group $A$ and $B 1$ and often have less virulence factors. All of these isolates are in human intestinal flora but dominantly are included in group $B 2$ and $D(11,12)$. Also the studies have shown that flora in the elderly population consist of the more virulent isolates (11). In another similar study it was reported that fecal flora related with the group B2 (3). The study conducted in Taiwan has shown that fecal $E$. coli isolates have high levels antibiotic resistance gene cassette containing class 1 integrons $(6,13)$. In addition, it was indicated that these integrons can be effective to horizontal spread of antibiotic resistance in the intestine. In these studies it was emphasized 
that studying normal flora surveillance in healthy people may be useful especially for estimating antibiotic resistance of infection agents $E$. coli isolates (6).

Lowest antibiotic susceptibility rate was found for ampisillin (53.33\%) between all antibiotics included this study. In the period of the study limited reporting of infectious agents in the laboratory was done on the basis of CLSI. Accordingly gentamicin (93.33\%) has the highest sensitivity rate in antibiotics group of $A$ to all isolates included in the study. All isolates in this study were found sensitive to imipenem, meropenem, ertapenem and cefepime and also sensitivity rates were found $(97.33 \%)$ and $(92.00 \%)$ for amikacin and piperacillin tazobactam respectively.

Similarly, in studies aimed to determine of antibiotic resistance in fecal flora $E$. coli isolates, different resistance rates are reported to ampicillin. Yang et al. (6) in their study made in China they found $50.42 \%$ resistance rates to ampicillin. In a different study in the United States conducted with cervicovaginal and rectal $E$. coli isolates they found no differences between antimicrobial susceptibility and resistance rates of these isolates and determined to antimicrobial resistance rate to ampicillin as $39.50 \%$ (14). Ampicillin resistance rates of fecal flora E. coli isolates are determined in Germany $16.70 \%$ in Serbia $42.00 \%$ in Korea $43.70 \%$ in Spain $58.50 \%$ and in Mexico 100\% (15-19).

As known, infections caused by ESBL positive $E$. coli isolates, caused serious epidemiological changes in infectious diseases in recent years $(20$, 21). Sixteen percent of the isolates included in the study were the ESBL-positive, the ESBL resistance was no observed in strains isolated from children. But due to the number of children in the study are low, the obtained results may not reflect the real situation. French researchers in their study investigated ESBL changes in fecal flora of healthy individuals; they showed ESBL production rate increased from $0.6 \%$ to $6 \%$ over a period of 5 years (22). Studies with healthy individuals in different countries, ESBL rates of fecal $E$. coli isolates were determined as $3.7 \%$ in Spain (23) and 5.8\% in Switzerland (24). Considering the differences between these ratio and our country results, although in the other study the people selected from healthy individuals, in our study people who admitted to hospital were included the study so this can be the reason of the differences. In India in 2013, antibiotic susceptibility of $E$. coli strains isolated from stool samples of children aged 3-14 were determined and evaluated the relationship between demographics data of children and the resistance. In the study it was observed that antibiotic resistance rates of $E$. coli isolated from stool samples were higher in children lives in rural and have mothers with low level education than children lives in city and have mothers higher level education. The study also indicated that ESBL rate was low (9\%) (1). Another result that obtained in this present study should be underlined although the less number of participants, quinolone resistance was observed in children. In this study 5D flora members $E$. coli strains evaluated quinolone resistance gene and found aac $\left(6^{\prime}\right) \mathrm{lb}$-cr gen positivity $20 \%$. QnrB positivity was determined in flora members $E$. coli as $6 \%$ (25).

Fecal flora elements frequently emerge as factor of UTI. Therefore, in this study antibiotic susceptibility of the $E$. coli isolates against to the antibiotics commonly used in UTI determined and compared the other studies results about the antibiotic susceptibility rates of uropathogen $E$. coli isolates. The susceptibilities of $E$. coli isolates to ampisillin, cefazolin, gentamicin, ampicillinsulbactam, trimethoprim - sulfamethoxazole, ciprofloxacin, amikacin and imipenem are found $53.33 \%, 81.33 \%, 93.33 \%, 77.33 \%, 74.67 \%, 74.67 \%$, $\% 84.67,97.33 \%, 100 \%$, respectively. Balasar et al in their study made in Konya, they reported $62.2 \% E$. coli rates in uropathogen agents and susceptibility rates to ampicilin $27.2 \%$, cephalothin $37 \%$, gentamicin $68 \%$, trimethoprim-sulfamethoxazole $46.5 \%$, ciprofloxacin 48\%, amikacin $97 \%$ and imipenem $99.4 \%$ (26). In another 
study made in Erzurum, Saracoglu et al. isolated $71.3 \%$ E. coli from urine samples and susceptibility rates to ampicillin, trimethoprim-sulfamethoxazole, ampicillin sulbactam, ciprofloxacin, gentamicin and amikacin reported as 47.9\%, 60.5\%, 77.3\%, 80.4\%, 96.7\%, 92.4\%, respectively (27). Terek and Basoglu in their study made in İzmir, found susceptibility rates to ampicillin 34.2\%, gentamicin $71.8 \%$, trimethoprim-sulfamethoxazole 51\%, ciprofloxacin $51.3 \%$, imipenem $100 \%$ (28). In our study ESBL positivity rate was found $16 \%$. In the other study in Turkey, it was detected as 38.6\% in İzmir (28), 13,9\% in outpatient and 27.5 in inpatient group in Malatya (29) and $20.2 \%$ in Ordu. The data obtained in this study are observed compatible in other studies that conducted with UTI agent $E$. coli isolates in Turkey.
In the study made in Kırıkkale, they were tested fecal flora $E$. coli in 2004. They found that the resistance rate of Amikacin was $1 \%$ and the rate of ESBL positive isolates were $3 \%$ (31). In our study, after nine years we have found that the resistance of Amikacin is 4\%, the rate of ESBL positive isolates are $16 \%$. This results are shown that the resistance is higher in time.

As a result, determination of antibiotic susceptibility of fecal $E$. coli isolates that source of infection and resistance genes, is very important for country surveillance studies. We believe monitoring to resistance profiles of fecal flora $E$. coli isolates especially in specific group patients in addition to infection agents is important for giving direction to empirical therapy.

\section{CONFLICTS of INTEREST}

The authors declare no conflicts of interest.

\section{REFERENCES}

1. Shakya P, Barrett P, Diwan V, Marothi $Y$, Shah $H$, Chhari N, et al. Antibiotic resistance among Escherichia coli isolates from stool samples of children aged 3 to 14 years from Ujjain, India. BMC Inf Dis, 2013; 13: 477-82.

2. Lynch JP, Clark NM, Zhanel GG. Evolution of antimicrobial resistance among Enterobacteriaceae (focus on extended spectrum B-lactamases and carbapenemases). Expert Opin Pharmacother, 2013; 14(2): 199-210.

3. Salyers AA, Gupta A, Wang Y. Human intestinal bacteria as reservoirs for antibiotic resistance genes. Trend Microbiol, 2004; 12(9): 412-6.
4. Nys S, Okeke IN, Kariuki S, Dinant GJ, Driessen C, Stobberingh EE. Antibiotic resistance of faecal Escherichia coli from healthy volunteers from eight developing countries. J Antimicrob Chemother 2004; 54(5): 952-5.

5. Moreno E, Andreu A, Pigrau C, Kuskowski MA, Johnson JR and Prats G. Relationship between Escherichia coli strains causing acute cystitis in women and the fecal $E$. coli population of the host. J Clin Microbiol, 2008; 46(8): 2529-34.

6. Yang $\mathrm{CM}$, Lin MF, Lin $\mathrm{CH}$, Huang $\mathrm{YT}$, Hsu CT, Liou ML. Characterization of antimicrobial resistance patterns and integrons in human fecal Escherichia coli in Taiwan. Jpn J Infect Dis, 2009; 62(3): 177-81. 
7. Medeiros AA. Evolution and dissemination of betalactamases accelerated by generations of betalactam antibiotics. Clin Infect Dis, 1997; 24(1): 19-45.

8. Jacoby GA. Extended-spectrum beta-lactamases and other enzymes providing resistance to oxyimino-beta-lactams. Infect Dis Clin North Am, 1997; 11(4): 875-87.

9. Czaja CA, Stamm WE, Stapleton AE, Roberts PL, Hawn TR, Scholes D, et al. Prospective cohort study of microbial and inflammatory events immediately preceding Escherichia coli recurrent urinary tract infection in women. J Infect Dis, 2009; 200(4): 52836.

10. Bingen E, Picard B, Brahimi N, Mathy S, Desjardins $P$, Elion J, Denamur E. Phylogenetic analysis of Escherichia coli strains causing neonatal meningitis suggests horizontal gene transfer from a predominant pool of highly virulent B2 group strains. J Infect Dis, 1998; 177(3): 642-50.

11. Vollmerhausen TL, Ramos NL, Gündoğdu A, Robinson W, Brauner A, Katouli M. Population structure and uropathogenic virulence-associated genes of faecal Escherichia coli from healthy young and elderly adults. J Med Microbiol, 2011; 60(5): 574-81.

12. Moreno E, Johnson JR, Pérez T, Prats G, Kuskowski MA, Andreu A. Structure and urovirulence characteristics of the fecal Escherichia coli population among healthy women. Microbes Infect, 2009; 11(2): 274-80.

13. Navidinia M, Peerayeh SN, Fallah F, Bakhshi B, Sajadinia RS. Phylogenetic grouping and pathotypic comparison of urine and fecal Escherichia coli isolates from children with urinary tract infection. Braz J Microbiol, 2014; 45(2): 509-14.

14. Hilbert DW, Paulish TE, Mordechai E, Adelson ME, Gygax SE, Trama JP. Antimicrobial non-susceptibility of cervico-vaginal and rectal Escherichia coli isolates is associated with phylogeny and plasmid carriage. Eur J Clin Microbiol Infect Dis, 2009; 28(11): 1399-403.

15. Stürmer T, Erb A, Marre R, Brenner H. Prevalence and determinants of antibiotic resistance in faecal Escherichia coli among unselected patients attending general practitioners in Southwest Germany. Pharmacoepidemiol Drug Saf, 2004; 13(5): 303-8.

16. Plavsić T. Markers of antimicrobial drug resistance in the most common bacteria of normal facultative anaerobic intestinal flora. Med Pregl, 2011; 64(1112): 613-7.
17. Kang HY, Jeong YS, Oh JY, Tae SH, Choi CH, Moon DC, et al. Characterization of antimicrobial resistance and class 1 integrons found in Escherichia coli isolates from humans and animals in Korea. J Antimicrob Chemother, 2005; 55(5): 639-44.

18. Domínguez E, Zarazaga $M$, Sáenz $Y$, Briñas $L$, Torres C. Mechanisms of antibiotic resistance in Escherichia coli isolates obtained from healthy children in Spain. Microb Drug Resist, 2002; 8(4): 321-7.

19. Calva JJ, Sifuentes-Osornio J, Cerón C. Antimicrobial resistance in fecal flora: longitudinal community-based surveillance of children from urban Mexico. Antimicrob Agents Chemother, 1996; 40(7): 1699-702.

20. Coque TM, Novais A, Carattoli A, Poirel L, Pitout $J$, Peixe $L$, et al. Dissemination of clonally related Escherichia coli strains expressing extendedspectrum B-lactamase CTX-M-15. Emerg Infect Dis, 2008; 14: 195-200.

21. Novais A, Cantón R, Valverde A, Machado E, Galán JC, Peixe L, et al. Dissemination and persistence of blaCTX-M-9 are linked to class 1 integrons containing CR1 associated with defective transposon derivatives from $\mathrm{Tn} 402$ located in early antibiotic resistance plasmids of IncHI2, IncP1-a, and IncFI groups. Antimicrob Agents Chemother, 2006; 50: 2741-50.

22. Leflon-Guibout V, Blanco J, Amaqdouf K, Mora A, Guize L, Nicolas-Chanoine MH. Absence of CTX-M enzymes but high prevalence of clones, including clone ST131, among fecal Escherichia coli isolates from healthy subjects living in the area of Paris, France. J Clin Microbiol, 2008; 46: 3900-5.

23. Valverde A, Coque TM, Sanchez-Moreno MP, Rollan $A$, Baquero F, Canton R. Dramatic increase in prevalence of fecal carriage of extended-spectrum beta-lactamase-producing Enterobacteriaceae during nonoutbreak situations in Spain. J Clin Microbiol, 2004; 42(10): 4769-75.

24. Geser NSR, Korczak BM, Beutin L, Hachler $\mathrm{H}$. Molecular identification of blaESBL genes from Enterobacteriaceae isolated from healthy human carriers in Switzerland. Antimicrob Agents Chemother, 2012; 56(3): 1609-12.

25. Pons MJ, Mosquito S, Gomes C, Del Valle LJ, Ochoa TJ, Ruiz J. Analysis of quinolone-resistance in commensal and diarrheagenic Escherichia coli isolates from infants in Lima, Peru. Trans $\mathrm{R}$ Soc Trop Med Hyg, 2014; 108(1): 22-8. 
26. Balasar $M$, Doğan $M$, Kandemir A, Feyzioğlu B, Hașimov Z, Baykan M. İdrar kültürlerinde, enfeksiyon etkenleri ve antibiyotik direnç oranları. Selçuk Tıp Dergisi, 2014; 30(2): 54-7.

27. Saraçoğlu KT, Fidan V, Pekel Ö, Saraçoğlu A, Kalkandelen S, Arpalı E. İdrar kültürlerinde izole edilen bakterilerin antibiyotik duyarlılıkları. J Clin Exp Invest, 2013; 4(3): 356-9.

28. Terek EG, Bașoğlu TM. Bir üniversite hastanesine gönderilen idrar kültürlerinde üreyen izolatların dağılımı ve antimikrobiyal duyarlılık profilinin incelenmesi. Ege J Med, 2013; 52(3): 136-40.
29. Duman Y, Güçlüer N, Serindağ A, Tekerekoğlu MS. Escherichia coli Sușlarında Antimikrobiyal Duyarlılık ve Genișlemiș Spektrumlu-Beta Laktamaz (GSBL) Varlığı. Fırat Tıp Derg, 2010; 15(4): 197-200.

30. Çetinkol Y, Yıldırım AA, Çakır FÖ. Extendedspectrum beta-lactamase activity and in vitro efficiency of ertapenem among Escherichia coli strains isolated from urine samples. Mediterr $\mathrm{J}$ Infect Microb Antimicrob, 2014; 3: 8-13.

31. Aksoy A, Göçmen SJ, KAçmaz B, Canver S. Antibiotic Resistance and Extended SpectrumBetalactamase Production in Fecal Escherichia coli Strains Isolated from Human and Cattle. ANKEM Derg, 2005; 19(3): 130-4. 